\title{
A study of tobacco consumption among the adult population in the urban slums of Silchar, Assam
}

\author{
Bhusan Nath A. ${ }^{{ }^{*}}$ \\ DOI: https://doi.org/10.17511/ijphr.2017.i2.02
}

${ }^{1 *}$ Ajoy Bhusan Nath, Assistant Professor, Department of Community Medicine, Silchar Medical College \& Hospital, Cachar, Assam, India.

\begin{abstract}
Objective: To assess the prevalence, the various forms and the different correlates of tobacco consumption in the Urban Slums of Silchar, Assam. Materials and Methods: A crossectional study was conducted in the Urban slums of Silchar Assam from January 2016 to December 2016 among 714 individuals aged 15 years and above. The data were collected in a pre designed and pre tested schedule by interview method and house to house visit in the selected slum. Results: This study revealed that as high as $55.46 \%$ individuals consumed tobacco in one form or the other. Chewing of tobacco was the most popular form of tobacco use $(55.81 \%)$. Marked gender differences were noted with $70.11 \%$ of male used tobacco in comparison to $38.98 \%$ of female. Common reasons found for tobacco consumption were peer pressure $(50.76 \%)$, Fun (35.35\%), Curiosity $(25.76 \%)$ and parents smoking habit $(5.30 \%)$. Initiation to tobacco habit in majority (54.29\%) began at 15 to 19 years of age. Majority (51.11\%) of tobacco smoker used 11 to 15 numbers of cigarettes/ bidis daily and $25 \%$ spent Rupees 31 to 50 per day. Tobacco consumption was found higher in illiterates $(58.20 \%)$, low socio-economic status $(58.38 \%)$, schedule caste $(57.18 \%)$ and daily wage earner $(59.26 \%)$ population. The prevalence was seen decreased as the education level increased. $69.75 \%$ respondents were aware of tobacco related health hazards. Majority gathered their knowledge from media $(58.23 \%)$ health personnel $(30.12 \%)$, friends $(15.16 \%)$ and family members $(5.62 \%)$. Conclusion: It is observed from this study that among the slum population tobacco consumption was much higher and younger subject have started tobacco use relatively at an early age. So Anti tobacco Education and Health Awareness campaign etc. should be initiated right from the beginning of the primary school as a part of prevention and control strategies of tobacco use.
\end{abstract}

Keywords: Tobacco consumption, Smoking, Khaini, Bidi

Corresponding Author

Ajoy Bhusan Nath, Assistant Professor, Department of Community Medicine, Silchar Medical College \& Hospital, Cachar, Assam, India.

Email: mnathchoudhury@gmail.com
How to Cite this Article

To Browse

Nath AB. A study of tobacco consumption among the adult population in the urban slums of Silchar, Assam. Public Health Rev Int J Public Health Res. $2017 ; 4(2): 38-44$.

Available From

https://publichealth.medresearch.in/index.php/ijphr/ article/view/60

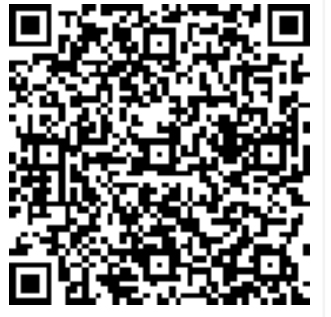

Manuscript Received 2017-04-04

Conflict of Interest No

Review Round 1
2017-04-14
Funding
Nil

Nil

(c) 2017 by Ajoy Bhusan Nath and Published by Siddharth Health Research and Social Welfare Society. This is an Open Access article licensed under a Creative Commons Attribution 4.0 International License https://creativecommons.org/licenses/by/4.0/ unported [CC BY 4.0].

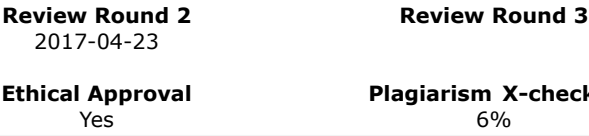

Review Round 3 2017-04-30

Note 


\section{Introduction}

Tobacco use is the single most preventable cause of adult death and disease in the world today. Globally an estimated 4 million death are caused by tobacco every year, 3 million in the industrialized countries and 1 million in the developing world [1].

In India, according to WHO (World Health Organization) estimates, 194 million men and 45 million women use tobacco in smoked or smokeless form [2]. Various forms of smoked tobacco used are bidi, cigarettes, pipe, hookah, chillum, chutta, dhumti and chewed tobacco are khaini (lime mixture), pan masala, zarda, gutkha and applied forms like snuff, creamy snuff etc [3].

Tobacco problems in the Northeast region are more complex than probably any other state in India, with a large burden of tobacco related diseases and death. The National Family Health Survey (NFHS-2) revealed that in Assam 34.9\% male population smoke tobacco while $48.2 \%$ chew tobacco. A fermented form of area nut known as 'Tamol' is chewed extensively in this region which increased the risk of developing oral and oesophagal cancer.

In the slum areas at Silchar, people lived in a condition of unhealthy, disease conductive, lack of safe drinking water, housing and environmental sanitation. Slums were initially thought to be temporary phenomena but this decade has been seen that slums are here to stay as long as the 'pull' force of urban prosperity and the 'push' force of rural poverty stay [4]. So far very few studies had been conducted in the Northeast states including Assam, particularly in the slum areas, the present study will give sufficient information regarding tobacco use and expected to highlight the strategies for prevention and control of it.

Thus, keeping in mind all those facts the study had been undertaken in the urban slum of Silchar with the following objectives:

(1) To assess the prevalence of tobacco consumption in the urban slums of Silchar.

(2) To study the various patterns of tobacco consumption, in the urban slums of Silchar.

(3) To assess the different correlates of tobacco consumption in the urban slums of Silchar and

(4) To assess awareness of tobacco related health hazards.

\section{Materials and Methods}

A community based cross-sectional study was conducted among urban slum populations of Silchar aged 15 years and above. Approval from the Ethical Committee, Silchar Medical College \& Hospital was taken prior to conduct the study.

The sample size was calculated as per the International Institute of Population Study, Mumbai which was designated as the nodal agency to undertake the World Health Survey in 2003, where they found the overall prevalence of tobacco consumption in Assam was 36\%.

Thus, $36 \%$ was taken as prevalence with permissible error of $10 \%$ (relative error).

$N=4 p q / L 2$ where $N=$ required sample size

$\mathrm{P}=$ Prevalence

$Q=(100-p)$

$L=10 \%$ of $p$ (relative error)

Applying this procedure the sample size was calculated as 711 . We selected 7 slums out of total 19 slums in the Silchar town by simple random sampling method and for uniform distribution of total number of respondents in each slum it was decided to take 102 respondents per slum, thus the total number of respondents came to 714 .

The data were collected from January 2016 to December 2016 in a pre-designed and pretested schedule by interview method and house to house visit in the selected slum.

All persons aged 15 years and above identified in each household and the general information of the family like type of family, housing, sanitation, family income, total members etc. were taken from the head of the family. Then the individual information like age, sex, religion, marital status, literacy, occupation, income, tobacco use status etc. were collected. This process was followed in every household.

For operational feasibility some accepted operational definitions were adopted like socioeconomic status which was determined as per B.G. Prasad method of socio-economic classification updated with CPI index May, 2014. Tobacco use definitions and criteria were based on standard WHO guidelines. All tobacco consumption were classified into six types namely cigarette, Bidi, Khaini, (tobacco lime mixture). 
Zarda (chewing tobacco mixture with slaked lime and flavourants), Gutkha (chewing tobacco containing areca nut and slaked lime) and mixed variety (smoking and chewing together).

Tobacco users: those who used tobacco (smoking or chewing) in the past and also at the time of study. Non-smokers: those who never use the tobacco, quitter: those who used tobacco previously, but have stopped at least for the past one year. The data collected on various aspects of study were compiled, tabulated and statistical analysis were done manually subjecting the data to the statistical tests.

\section{Results}

In the present study 714 individuals (Male 378 and Female 336) aged 15 years and above were interviewed in the urban slums of Silchar, Assam. It was observed that the overall prevalence of tobacco consumption for both male and female were 396 $(55.46 \%)$ (table : 1 ).

The prevalence of tobacco consumption was higher among males 265 (70.11\%) than females $131(38.98 \%)$ and the highest percentage of tobacco users $(70.64 \%)$ were 45 to 49 years of age group (table : 2).

The age of initiation of tobacco use was highest in $15-19$ years age group (54.29\%) (table : 3 ). The reasons for tobacco use were peer pressure $(50.76 \%)$ followed by fun $(35.35 \%)$, curiosity $(25.76 \%)$ and influence of smoker parent $(5.30 \%)$ (table : 4).

Majority of tobacco user used Khaini (32.32\%) followed by Bidi $(25.50 \%)$, Gutkha (13.64\%), mixed variety $(10.10 \%)$ and Cigarette $(8.59 \%)$ (table : 5$)$.

Among the tobacco users the percentage of male tobacco smoker is more $107(40.38 \%)$ in comparison to female $28(21.37 \%)$ whereas the female tobacco chewers $99(75.57 \%)$ were highest than male $122(46.04 \%)$ and amongst mixed users $36(13.58 \%)$ were male and $4(3.05 \%)$ were female.

Among the tobacco smokers $(n=135), 55.11 \%$ used 11-15 number of sticks of cigarettes/bidis daily followed by $23.7 \%$ who used $6-10$ number of sticks and $20 \%$ used more than 15 nos. of sticks of cigarettes/bidis per day.

Regarding expenditure, it was seen that $50 \%$ of the tobacco users spent Rs. 11-20 daily, 25\% spent Rs.
21-30 daily, $16.92 \%$ spent Rs. $31-50$ daily and $8.08 \%$ spent more than Rs. 50 per day.

The prevalence of tobacco use was found highest in married $301(60.56 \%)$ followed by widow 6 $(54.55 \%)$ and lowest in unmarried $89(43.20 \%)$ population (table : 6 ).

It was found that the prevalence of tobacco use was highest in illiterates $(58.20 \%)$ followed by primary education $(54.19 \%)$, HSLC $(47.83 \%)$, graduation and above (37.50\%) (table: 7 ).

Regarding occupation the prevalence of tobacco use was highest among daily wage earner $(67.49 \%)$ and lowest among students (29.63\%) (table: 8 ).

It was also observed that majority $(58.38 \%)$ of tobacco users belonged to low socio-economic status.

Majority $(69.75 \%)$ of the total respondents (714) were aware of the ill effects of tobacco. They acquired the knowledge from media (58.23\%) followed by health personnel $(30.12 \%)$, friends $(15.66 \%)$ and family members (5.62\%).

It was also found that among the quitters $(n=50)$ most of them (62\%) quitted tobacco use due to ill health, $36 \%$ for family opposition and $6 \%$ for knowing its ill effects.

Table-1: Distribution of respondents according to tobacco users and non-users

\begin{tabular}{|l|l|l|}
\hline \multicolumn{1}{|c|}{ Tobacco } & \multicolumn{1}{|c|}{ No. of respondents } & \multicolumn{1}{c|}{ Percentage } \\
\hline User & 396 & 55.46 \\
\hline Non-users & 318 & 44.54 \\
\hline Total & 714 & 100 \\
\hline
\end{tabular}

Table-2: Distribution of respondents according to age and tobacco use

\begin{tabular}{|l|l|l|l|}
\hline $\begin{array}{c}\text { Age group (in } \\
\text { years) }\end{array}$ & \multicolumn{1}{|c|}{$\begin{array}{c}\text { Total no. of } \\
\text { respondents }\end{array}$} & $\begin{array}{c}\text { No. of tobacco } \\
\text { user }\end{array}$ & \multicolumn{1}{c|}{ ercentag } \\
\hline $15-19$ & 65 & 9 & 13.85 \\
\hline $20-24$ & 76 & 19 & 25.0 \\
\hline $25-29$ & 84 & 39 & 46.43 \\
\hline $30-34$ & 85 & 53 & 62.35 \\
\hline $35-39$ & 103 & 57 & 65.04 \\
\hline $40-44$ & 114 & 78 & 68.42 \\
\hline $45-49$ & 109 & 77 & 70.64 \\
\hline$>50$ & 78 & 54 & 69.23 \\
\hline Total & 714 & 396 & 55.46 \\
\hline
\end{tabular}


Table-3: Distribution of tobacco users according to age of initiation of tobacco use

\begin{tabular}{|l|l|l|}
\hline Age of initiation (in years) & No. of tobacco user & Percentage \\
\hline$<15$ & 32 & 8.08 \\
\hline $15-19$ & 215 & 54.29 \\
\hline $20-24$ & 99 & 25.0 \\
\hline $25-29$ & 40 & 10.10 \\
\hline$>30$ & 10 & 2.53 \\
\hline Total & 396 & 100 \\
\hline
\end{tabular}

Table-4: Distribution of tobacco users according to their reason for tobacco use

\begin{tabular}{|l|l|l|}
\hline \multicolumn{1}{|c|}{ Reason } & \multicolumn{1}{|c|}{ No. of tobacco users $(\mathrm{n}=\mathbf{3 9 6})$} & Percentage \\
\hline Curiosity & 102 & 25.76 \\
\hline Fun & 140 & 35.35 \\
\hline Peer pressure & 201 & 50.76 \\
\hline Parent smoker & 21 & 5.30 \\
\hline
\end{tabular}

N.B.: Respondents have given multiple responses.

Table-5: Distribution of tobacco users according to type of tobacco use

\begin{tabular}{|l|l|l|}
\hline \multicolumn{1}{|c|}{ Type of tobacco } & No. of users & \multicolumn{1}{c|}{ Percentage } \\
\hline Cigarette & 34 & 8.59 \\
\hline Bidi & 101 & 25.50 \\
\hline Khaini & 128 & 32.32 \\
\hline Zarda & 39 & 9.85 \\
\hline Gutkha & 54 & 13.64 \\
\hline Mixed variety & 40 & 10.10 \\
\hline Total & 396 & 100 \\
\hline
\end{tabular}

Table-6: Distribution of respondents according to marital status \& tobacco use

\begin{tabular}{|l|l|l|l|}
\hline \multicolumn{1}{|c|}{$\begin{array}{c}\text { Marital } \\
\text { status }\end{array}$} & \multicolumn{1}{|c|}{$\begin{array}{c}\text { Total no. of } \\
\text { respondents }\end{array}$} & \multicolumn{1}{c|}{$\begin{array}{c}\text { No. of tobacco } \\
\text { user }\end{array}$} & $\begin{array}{c}\text { Percentag } \\
\text { e }\end{array}$ \\
\hline Married & 497 & 301 & 60.56 \\
\hline Unmarried & 206 & 89 & 43.20 \\
\hline Widow & 11 & 06 & 54.55 \\
\hline Total & 714 & 396 & 55.46 \\
\hline
\end{tabular}

$X_{2}=17.76, d f=2, p<0.05$

Table-7: Distribution of respondents according to literacy status and tobacco use

\begin{tabular}{|l|l|l|l|}
\hline Literacy status & \multicolumn{1}{|c|}{$\begin{array}{c}\text { Total no. of } \\
\text { respondents }\end{array}$} & \multicolumn{1}{|c|}{$\begin{array}{c}\text { No. of tobacco } \\
\text { user }\end{array}$} & $\begin{array}{l}\text { Percentag } \\
\text { e }\end{array}$ \\
\hline Illiterate & 378 & 220 & 58.20 \\
\hline Primary school & 179 & 97 & 54.19 \\
\hline High school & 115 & 60 & 52.17 \\
\hline HSLC passed & 23 & 11 & 47.83 \\
\hline HS passed & 11 & 05 & 45.45 \\
\hline $\begin{array}{l}\text { Graduate and } \\
\text { above }\end{array}$ & 08 & 03 & 37.50 \\
\hline Total & 714 & 396 & 55.46 \\
\hline
\end{tabular}

$\mathrm{X} 2=3.81, \mathrm{df}=5, \mathrm{p}>0.05$

Table-8: Distribution of respondents according to occupation and tobacco use

\begin{tabular}{|l|l|l|l|}
\hline \multicolumn{1}{|c|}{ Occupation } & \multicolumn{1}{|c|}{$\begin{array}{c}\text { Total no. of } \\
\text { respondents }\end{array}$} & \multicolumn{1}{|c|}{$\begin{array}{c}\text { No. of tobacco } \\
\text { user }\end{array}$} & $\begin{array}{l}\text { Percentag } \\
\text { e }\end{array}$ \\
\hline $\begin{array}{l}\text { Daily wage } \\
\text { earner }\end{array}$ & 366 & 247 & 67.49 \\
\hline Skilled worker & 54 & 32 & 59.26 \\
\hline Own business & 132 & 67 & 50.76 \\
\hline Service & 46 & 21 & 45.65 \\
\hline Housewife & 73 & 15 & 20.55 \\
\hline Unemployed & 16 & 06 & 37.50 \\
\hline Student & 27 & 08 & 29.63 \\
\hline Total & 714 & 396 & 55.46 \\
\hline
\end{tabular}

$X 2=70.09, d f=6, p<0.001$

\section{Discussion}

In the present study it was observed that the prevalence of tobacco use among the urban slum population of Silchar aged 15 years and above was $55.46 \%$. Pandey G. K. et al. in their study also observed the overall tobacco consumption in Hooghly district, Calcutta was 51\% [5]. Majority of the tobacco users belonged to 45-49 years of age (70.64\%). Similar observations were also made by other workers $[8,10]$.

Regarding type of tobacco use it was observed that majority used Khaini (32.32\%), 25.5\% used bidi, $13.64 \%$ used gutkha and $10.10 \%$ used mixed variety. Shah and Vaites in their study among the pavement dwellers also found that $30.3 \%$ used bidi, $20 \%$ used gutkha, $8 \%$ used cigarette and $2.3 \%$ used Khaini [6].

The age of initiation of tobacco use was seen highest (54.29\%) in 15 to 19 years age group. Pandey G.K. et al reported in their study that the age of initiation was highest (55.20\%) in 20 years and above age group [5]. Similar observation were also noticed by other workers $[9,12]$.

The reason for initiation of tobacco use was seen as peer pressure $(50.76 \%)$, fun $(35.35 \%)$, curiosity (25.76\%) and parent smoking habit (5.30\%). Other Indian studies also mentioned similar observations in their study $[5,12]$. The relationship between tobacco use and religion was found significant in present study $(P<0.05)$. The tobacco use among Hindus (58.70\%) is higher than Muslims (50.53\%). Rani $M$ et al [7] also found significant relation between tobacco use and the religion in their study. 
Rani $\mathrm{M}$ et al [7] observed in their study that $35.2 \%$ tobacco users were schedule caste followed by $34.4 \%$ schedule tribe, $28.1 \%$ other backward class and others $2.30 \%$. Other workers also found similar caste differences $[9,10,13]$.

Among marital status and tobacco use it was seen that $60.56 \%$ of tobacco users were married followed by unmarried $43.20 \%$ and window $54.55 \%$. This differences were found significant $(P<0.05)$. Occupation was found to had a role on tobacco use, the highest prevalence was observed among daily wage earner $(67.49 \%)$. This was found significant $(P<0.001)$. Sharma $R$ et al \& Bala DV et al. also found in their study the similar findings $[8,9]$.

It was also observed that the lower socio-economic class of people used tobacco at a higher rate (58.38\%). Gupta I and Sankar D \& Rani M et al had found that the higher prevalence of tobacco use among lower income group of people $(54.3 \%)$ $[7,10]$. The prevalence of tobacco use was found highest among illiterates population (58.20\%).

It decreased as the education level increased ( $P>0.05$ ). NFHS-2 revealed that $35 \%$ of the tobacco users were illiterate. Pandey GK et al also observed in their study that graduate teachers used less tobacco $(20 \%)$ than non-graduate teacher (55.75\%) [5].

Again among males tobacco use was very high 265 $(70.11 \%)$ than female 131 (38.98\%). This differences were found significant $(P<0.001)$. Other authors found in their studies that the prevalence of tobacco use among males were high $[5,7,9]$. Regarding tobacco smokers, the prevalence of male smoker is more $(40.38 \%)$ than female smoker $(21.37 \%)$ which was found significant.

Again the prevalence of female chewers $(75.57 \%)$ was higher than male chewers $(46.04 \%) \quad(P<0.01)$ and among mixed tobacco users the males were higher $(13.58 \%)$ than female mixed user $(3.05 \%)$ $(P<0.01)$. These differences were found significant.

Bala DV et al \& Sinha DN et al also found in their study that the prevalence of male smoker and female chewers were as high as $31.60 \%$ and $25.86 \%$ respectively $[2,9]$. Regarding health awareness among tobacco users (396) and non users (318) about the ill effects of tobacco, it was observed that the knowledge about the ill effects of tobacco among users were $65.40 \%$ and non users were $75.16 \%$. These differences were found significant.
Roychoudhury S and Sinha DN observed in their study that most of the tobacco users $(88.6 \%)$ knew the serious health consequences of tobacco use [14]. Sinha DN et al. also reported that the majority of tobacco users $(66 \%)$ were aware of the dangers of smoking [15]. It was also observed that among the quitter $(n=50)$, majority $(46 \%)$ quitted tobacco at 45 to 54 years of age. The reason of quitting was mainly due to health ground (62\%) Azevedo A et al [16] also found $18.70 \%$ quitters quitted tobacco use at the age group of 15 to 19 years due to ill health.

\section{Conclusion}

It is evident from this study that tobacco consumption among slum population was much higher and the younger subjects have started tobacco use relatively at an early age. Therefore, prevention strategies like anti-tobacco education should be initiated right from the beginning of the primary school.

Besides, IEC activities should be targeted specially to the teenage population, specific messages targeting male and female depending upon the pattern of tobacco use. Messages to the adult population should include the influence of smoker parents to children and the effects of passive smoking to the immediate family members like pregnant women and children.

In the health sector, tobacco cessation centre to be well equipped with infrastructure and man power to help the tobacco users. The urban and rural satellite centres also to be well guided by the tobacco cessation centre. Thus a multi-disciplinary approach of health and other sector along with PRI and media is essential to disseminate the specific knowledge to the community.

The people to be made aware of the Government legislation and to follow the tobacco control legislation with full and whole hearted participation of all Government, non-Government agencies and involvement of every member of the society. Last but not the least, to motivate the tobacco users to quit tobacco and affirm the quitter to sustain.

\section{Reference}

01. Gupta PC, Sinha DN. Tobacco research in India. Indian J Public Health. 2004 Jul-Sep;48(3)1034.

[Crossref] 
02. Sinha DN, Gupta PC, Pednekar MS. Tobacco use in a rural area of Bihar, India. Indian Journal of Community Medicine. 2003,28(4)167-170. [Crossref]

03. Bhonsle RB, Murti PR, Gupta PC. Tobacco habits in India, control of tobacco related cancers and other diseases, proceeding of an International Symposium, Gupta PC. Oxford University press, Bombay. 25-46;1992.

[Crossref]

04. Potdar, Ramesh D. Training of paediatric primary care in urban Ghettos and Slum. International Child Health. 1994;5(4)11-13.

[Crossref]

05. Pandey GK, Raut DK, Hazra S, Vajpayee A, Pandey A, Chatterjee P. Patterns of tobacco use amongst school teachers. Indian journal of public health. $2001 ; 35(3) 82-87$.

[Crossref]

06. Shah S, Vaite S. Pavement dwellers in Mumbai, India, prioritizing tobacco over basic needs, In Efroymson D ed, Tobacco and poverty. observation from India and Bangladesh. 2002.

[Crossref]

07. Rani M, Bonu S, Jha P, Nguyen SN, Jamjoum L. Tobacco use in India- prevalence and predictors of smoking and chewing in a national cross sectional household survey. Tob Control. 2003 Dec;12(4)e4.

[Crossref]

08. Sharma R, Pednekar MS, Rehman AU, Gupta R. Tobacco use among school personnel in Rajasthan, India. Indian J Cancer. 2004 OctDec;41(4)162-6.

[Crossref]

09. Bala DV, Bodiwala IN, Patel DD, Shah PM. Epidemiological determinants of tobacco use in Gujarat state, India. Indian journal of Community Medicine; 2006;31(3). [Crossref]
10. Gupta I, Sankar D. Tobacco consumption in India- a new look using data from the National Sample Survey. J Public Health Policy. 2003;24(3-4)233-45.

[Crossref]

11. National Family Health Survey 2 Report, Assam. 1998-99. .

[Crossref] [PubMed] [Google Scholar] [Crossref]

12. Sharma N, Singha MM, Ingle GK, Jiloha RC. An epidemiological study of cigarette smoking among male college students of Delhi University. Indian Journal of Public health. 2006;31(1).

[Crossref]

13. Subramanian SV, Nandy S, Kelly M, Gordon D, Davey Smith G. Patterns and distribution of tobacco consumption in India- cross sectional multilevel evidence from the 1998-9 national family health survey. BMJ. 2004 Apr3;328(7443)801-6.

[Crossref]

14. Roychoudhury S, Sinha DN. Tobacco control practices in 25 schools of West Bengal. Indian Journal of Public Health. 2004;48(3)128-130. [Crossref]

15. Sinha DN, Gupta PC, Pednekar M. Tobacco use among students in Bihar (India). Indian J Public Health. 2004 Jul-Sep;48(3)111-7.

[Crossref]

16. Azevedo A. , Machado A. P. \& Barros H.

: Tobacco smoking among Portuguese high school students : Bulletin of world health organisation, 1999, 77(6): 509-513 [Crossref] 